\title{
Deletion of Presenilin 1 Hydrophilic Loop Sequence Leads to Impaired $\gamma$-Secretase Activity and Exacerbated Amyloid Pathology
}

\author{
Yu Deng, ${ }^{1}$ Leonid Tarassishin, ${ }^{4}$ Verena Kallhoff, ${ }^{1,2}$ Erica Peethumnongsin, ${ }^{1,3}$ Ling Wu, ${ }^{1}$ Yue-Ming Li, ${ }^{4}$ and Hui Zheng ${ }^{1,2,3}$ \\ ${ }^{1}$ Huffington Center on Aging, ${ }^{2}$ Department of Molecular and Human Genetics, and ${ }^{3}$ Interdepartmental Program of Cellular and Molecular Biology, Baylor \\ College of Medicine, Houston, Texas 77030, and ${ }^{4}$ Molecular Pharmacology and Chemistry Program, Memorial Sloan-Kettering Cancer Center, New York, \\ New York 10021
}

\begin{abstract}
$\gamma$-Secretase processing of the amyloid precursor protein (APP) generates $\mathrm{A} \beta_{40}$ and $\mathrm{A} \beta_{42}$, peptides that constitute the principal components of the $\beta$-amyloid plaque pathology of Alzheimer's disease (AD). The $\gamma$-secretase activity is executed by a high-molecular-weight complex of which presenilin 1 (PS1) is an essential component. PS1 is a multi-pass membrane protein, and the large hydrophilic loop domain between transmembrane domains 6 and 7 has been shown to interact with various proteins. To determine the physiological function of the loop domain, we created a strain of PS1 knock-in mice in which the exon 10, which encodes most of the hydrophilic loop sequence, was deleted from the endogenous PS1 gene. We report here that the homozygous exon 10-deleted mice are viable but exhibit drastically reduced $\gamma$-secretase cleavage at the $\mathrm{A} \beta_{40}$, but not the $\mathrm{A} \beta_{42}$, site. Surprisingly, this reduction of $\mathrm{A} \beta_{40}$ is associated with exacerbated plaque pathology when expressed on APP transgenic background. Thus, the PS1 loop plays a regulatory role in $\gamma$-secretase processing, and decreased $\mathrm{A} \beta_{40}$, not increased $\mathrm{A} \beta_{42}$ is likely the cause for the accelerated plaque deposition in these animals. Our finding supports a protective role of $\mathrm{A} \beta_{40}$ against amyloid pathology and raises the possibility that impaired $\gamma$-secretase activity could be the basis for AD pathogenesis in general.
\end{abstract}

Key words: Alzheimer's disease; amyloid peptides; $\gamma$-secretase; presenilin; knock-in mice; homodimer

\section{Introduction}

Mammalian presenilins (PS) consist of two homologous proteins, PS1 and PS2. They are indispensable for processing the amyloid precursor protein (APP) at the $\gamma$-secretase site to generate $\mathrm{A} \beta_{40}$ and $\mathrm{A} \beta_{42}$, which proceed to deposit as the main components of the $\beta$-amyloid plaques characteristic of Alzheimer's disease (AD) (for review, see Annaert and De Strooper, 2002). Through similar mechanisms defined as regulated intramembrane proteolysis (Brown et al., 2000), presenilins are required for processing and signaling of Notch (De Strooper et al., 1999) and have been implicated in the processing of a growing list of type I membrane proteins (for review, see Kopan and Ilagan, 2004).

The PS-dependent $\gamma$-secretase activity requires the formation of a high-molecular-weight complex containing nicastrin, Aph1, and Pen2 (for review, see Iwatsubo, 2004). The active complex is assembled in a sequential and interdependent manner through

Received Dec. 16, 2005; revised Feb. 2, 2006; accepted Feb. 24, 2006.

This work was supported by National Institutes of Health Grants NS40039, AG20670, and AG21141 (H.Z.) and AG026660 (Y.-M.L.) and by the Ellison Medical Foundation (H.Z.). V.K. is a Baylor Research Advocates for Student Scientists Scholar, and E.P. is in the Medical Scientist Training Program of Baylor College of Medicine. H.Z. and Y.-M.L. are Zenith fellows of the Alzheimer's Association. We thank D. Beasley, X. Chen, and N. Aithmitti for expert technical support and Drs. N. Timchenko for assistance with gel filtration, W. He and R. Yan for ELISA, and W.-K. Shum and E. Koo for discussions.

Correspondence should be addressed to Hui Zheng, Huffington Center on Aging, Baylor College of Medicine, One Baylor Plaza, M320, Houston, TX 77030. E-mail: huiz@bcm.tmc.edu.

DOI:10.1523/JNEUROSCI.5384-05.2006

Copyright $\odot 2006$ Society for Neuroscience $\quad 0270-6474 / 06 / 263845-10 \$ 15.00 / 0$ the endoplasmic reticulum and Golgi compartments. Nicastrin was shown to function as the receptor for the $\gamma$-secretase substrates (Shah et al., 2005), and Pen2 facilitates the endoproteolytic cleavage of full-length PS to its N-terminal fragment (NTF) and C-terminal fragment (CTF) (Iwatsubo, 2004). Based on the high-molecular-weight nature of the $\gamma$-secretase complex, Schroeter et al. (2003) presented data to support the presence of presenilin homodimers at the core of the $\gamma$-secretase complex, and follow-up studies showed that the transmembrane domains are essential for dimer formation (Cervantes et al., 2004). Wolfe et al. (1999) reported that presenilins are a novel class of diaspartyl protease in which the conserved aspartate at residues 257 and 385 within transmembrane (TM) domains 6 and 7, respectively, are the active sites (Wolfe et al., 1999). This notion is corroborated by data demonstrating that PS1 can be directly labeled by transition-state $\gamma$-secretase inhibitors (Esler et al., 2000; $\mathrm{Li}$ et al., 2000b). Consistent with these findings, using our PS1 "rescue" system, we reported that PS1 containing the D257A mutation results in the loss of $\gamma$-secretase activity in vivo (Xia et al., 2002).

PS1 is a multi-pass membrane protein with a large hydrophilic loop domain, through which it binds to multiple proteins, including $\beta$-catenin and $\mathrm{N}$ - and $\mathrm{E}$-cadherins (Georgakopoulos et al., 1999; Kang et al., 1999). The association of PS1 with the cadherin/catenin complex and its redistribution to the site of cell-cell contacts support a role of PS1 in cadherin/catenin- 
mediated cell adhesion and synaptic function (Georgakopoulos et al., 1999; Baki et al., 2001). A potential link between PS1cadherin interaction and $\gamma$-secretase activity was presented by the same group showing that the cadherins also undergo PSdependent processing and by this means regulate the cadherin/ catenin complex assembly and intracellular signaling (Marambaud et al., 2002, 2003). Therefore, although the hydrophilic loop domain is known to be dispensable for PS1 $\gamma$-secretase activity (Saura et al., 2000; Xia et al., 2002), it may play a modulatory role for this cleavage event.

The interaction of PS1 with $\beta$-catenin has been proposed to negatively regulate $\beta$-catenin stability and its downstream signaling pathway (Kang et al., 1999; Soriano et al., 2001; Kang et al., 2002). We have shown that loss of PS1 leads to skin tumorigenesis, and this phenotype is associated with upregulation of the signaling pool of $\beta$-catenin (Soriano et al., 2001; Xia et al., 2001; Kang et al., 2002), indicating that the deregulation of the $\beta$-catenin pathway could be the cause for the tumorigenic phenotype. However, skin tumor formation is also a prominent feature in mice with conditional deletion of Notch 1 in epidermis, and, interestingly, the $\beta$-catenin pathway is upregulated as well (Nicolas et al., 2003). Therefore, regulation of $\beta$-catenin by PS1 could be attributed directly to their physical interactions through the PS1 hydrophilic loop domain or indirectly through Notch. The degree of contribution of these two pathways in vivo remains to be established.

To genetically uncouple the pathways of PS1 on $\beta$-catenin interaction and Notch regulation, we created a strain of PS1 knock-in mice containing a deletion of exon 10 encoding most of the hydrophilic loop sequence necessary for $\beta$-catenin binding. Characterization of these animals revealed novel insights into the physiological function of PS1 on $\beta$-catenin regulation, PS1 secondary structure, and the unexpected role of the loop domain on $\gamma$-secretase activity and amyloid pathogenesis.

\section{Materials and Methods}

Antibodies and animals. The following antibodies were used in this study: PS1N and PS1C polyclonal antibodies were raised against PS1 $\mathrm{N}$-terminal peptide (1-15 amino acids) and C-terminal peptide (455467 amino acids), respectively, and APPC was raised against the last 15 amino acids of the human APP sequence. Mouse anti-PS1 loop monoclonal antibody was purchased from Chemicon (Temecula, CA). Antinicastrin antibody was raised against $688-708$ amino acids of the protein and was available from Affinity BioReagents (Golden, CO). Anti-Aph1 $\alpha$ and anti-Pen2 antibodies were from Zymed (San Francisco, CA), anti$\beta$-catenin, anti-N-cadherin, and anti-glycogen synthase kinase $3 \beta$ $(\mathrm{GSK} 3 \beta)$ were purchased from BD Transduction Laboratories (Lexington, KY), anti- cyclin-dependent kinase 5 (Cdk5) (C-8) was from Santa Cruz Biotechnology (Santa Cruz, CA), and 6E10 monoclonal antibody was obtained from Signet Laboratories (Dedham, MA).

The generation of mice with deletion of exon 10 of the mouse PS1 gene (PS1 $\triangle \mathrm{E} 10$ ) is described in supplemental Methods and Figure S1 (available at www.jneurosci.org as supplemental material). All animal experiments were performed in accordance with the Baylor College of Medicine Institutional Animal Care and Use Committee and with national regulations and policies.

Brain lysate preparation and Western blotting. Half of an adult mouse forebrain was homogenized using Polytron PT1200C (Kinematica, Basel, Switzerland) in $2 \mathrm{ml}$ of ice-cold lysis buffer [ $50 \mathrm{~mm}$ Tris, $\mathrm{pH} 7.5,150 \mathrm{~mm}$ NaCl, 1 mм EDTA, 1 mм EGTA, 5 mm NaF, 10\% glycerol, 1 mм DTT, 0.2 $\mu \mathrm{M}$ Microcystin-LR, $1 \mathrm{mM} \mathrm{Na}_{3} \mathrm{VO}_{4}$, and complete protease inhibitor (Roche Products, Welwyn Garden City, UK)] with 1\% detergent [CHAPSO (3-[(3-cholamidopropyl)dimethylammonio]-2-hydroxy-1propanesulfonate), digitonin, or SDS] as indicated. The homogenate was then subjected to sonication using Branson (Danburg, CT) Sonifier 450 set at output 3 for $30 \mathrm{~s}$. The homogenate was kept on ice for another 15 $\mathrm{min}$ and then subjected to ultracentrifugation at $100,000 \times g$ for $1 \mathrm{~h}$ with a Beckman Instruments (Fullerton, CA) SW60 rotor at $4^{\circ} \mathrm{C}$. The supernatant was collected from the brain lysate, and protein concentration was determined by DC protein assay (Bio-Rad, Hercules, CA). For western blotting analysis of PS1, the samples were heated at $65^{\circ} \mathrm{C}$ for $10 \mathrm{~min}$; for other protein analysis, the samples were boiled at $95^{\circ} \mathrm{C}$ for $5 \mathrm{~min}$. Brain lysates (30-50 $\mu \mathrm{g}$ of proteins, depending on target protein analyzed) were loaded onto $10-15 \%$ SDS-PAGE gel. A total of $12 \%$ Tris-tricine gels were used for $\triangle \mathrm{E} 10-\mathrm{CTF}$ and APP-CTF detection, and other proteins were analyzed by Tris-glycine gels. After electrophoresis, the proteins were transferred onto nitrocellulose membrane (Bio-Rad). The membrane was blocked in PBS with $0.1 \%$ Tween 20 and 5\% nonfat milk at room temperature for $1 \mathrm{~h}$. The membrane was incubated with the indicated primary antibodies for $2 \mathrm{~h}$ at room temperature or overnight at $4^{\circ} \mathrm{C}$. After extensive washing, the membrane was incubated with horseradish peroxidase-conjugated secondary antibody for $2 \mathrm{~h}$. After additional washing with TBST buffer (TBS and Tween 20), the blot was visualized by enhanced chemiluminescence according to the instructions of the manufacturer (Amersham Biosciences, Arlington Heights, IL).

Immunoprecipitation. Brain lysates (0.5-2 mg) lysed in 1\% digitonin or $1 \%$ CHAPSO lysis buffer were incubated with antibodies with gentle rocking at $4^{\circ} \mathrm{C}$ overnight. Protein A agarose beads ( $20 \mu \mathrm{l}$ of $50 \%$ slurry; Invitrogen, Carlsbad, CA) were preequilibrated with ice-cold lysis buffer, applied to the protein-antibody mixture, and incubated for another 1-2 $\mathrm{h}$ at $4^{\circ} \mathrm{C}$. The beads were then centrifuged down and washed extensively with lysis buffer, $5 \mathrm{~min}$ for three to five times. A total of $50 \mu \mathrm{l}$ of $1 \times$ SDS loading dye were added into the immunoprecipitates, which were subjected to Western blot analysis.

For immunoprecipitation (IP) using PS1N polyclonal antibody, the anti-PS1N antibody or control rabbit IgG was first cross-linked to protein A agarose beads by disuccinimidyl suberate (Pierce, Rockford, IL) according to the instructions of the manufacturer. Briefly, PS1N or rabbit IgG antibodies $(40 \mu \mathrm{l})$ were diluted with the antibody binding/washing buffer ( 50 mm sodium borate, $\mathrm{pH} 8.2$ ) and incubated with $600 \mu \mathrm{l}$ of $50 \%$ protein A agarose beads for $1 \mathrm{~h}$ at room temperature. After extensive washing with the antibody binding/washing buffer, the beads were incubated with $5 \mathrm{mg}$ of disuccinimidyl suberate dissolved in $0.5 \mathrm{ml}$ of DMSO for $1 \mathrm{~h}$ and then diluted with $0.75 \mathrm{ml}$ of cross-linking buffer $(0.15 \mathrm{M} \mathrm{NaCl}$ and $0.1 \mathrm{M} \mathrm{Na} 2 \mathrm{PO} 4, \mathrm{pH} 7.2$ ). After incubation, the beads were washed extensively with the antibody binding/washing buffer, and $2 \mathrm{ml}$ of blocking buffer ( $0.1 \mathrm{M}$ ethanolamine, $\mathrm{pH} 8.2)$ was applied to the washed beads and mixed for $15 \mathrm{~min}$. The beads were washed with $5 \mathrm{ml}$ of elution buffer (0.1 M glycine-HCl, $\mathrm{pH} 2.8)$ to remove the uncross-linked antibodies and were further washed with the binding/washing buffer. Finally, protein A beads cross-linked with PS1N antibody were equilibrated with lysis buffer for immunoprecipitation.

Gel filtration chromatography. Two milligrams of brain lysates $(150 \mu \mathrm{l})$ in $1 \%$ digitonin lysis buffer from the wild-type (WT) and PS1 $\Delta \mathrm{E} 10$ mice were applied to Bio-Sil SEC250-5 HPLC column (Bio-Rad). The column was eluted with $20 \mathrm{ml}$ of elution buffer (20 mM Tris-HCl, pH 7.4, and 150 $\mathrm{mm} \mathrm{NaCl}$ ) at a flow rate $0.3 \mathrm{ml} / \mathrm{min}$. The elution was collected at 0.3 $\mathrm{ml} /$ fraction. A total of $40 \mu \mathrm{l}$ of each fraction eluted were analyzed by Western blotting using PS1N, PS1C, nicastrin, $\beta$-catenin, GSK $3 \beta$, and Cdk5 antibodies. The molecular weight (in kilodaltons) of gel filtration fractions was determined by fractioning of blue dextran (Vo) and the gel filtration standard (Bio-Rad) under the same conditions.

$\gamma$-Secretase activity and photo-labeling assays. $\gamma$-Secretase activity was assayed using a peptide substrate (Li et al., 2000a,b). Mouse brain membrane proteins were solubilized with $1 \%$ CHAPSO. Mouse brain membrane or solubilized $\gamma$-secretase was incubated with the substrate, and $\gamma$-secretase-mediated 40 and 42 site cleavages were detected by ECL using the ruthenylated G2-10 and G2-11 antibodies, respectively. The nonspecific cleavage is defined as signal in the presence of $1 \mu \mathrm{M} \gamma$-secretase inhibitor, tert-butyl $(2 S, 3 R, 5 R)-6-((S)-1-((S)$-1-amino-1-oxo-3-phenylpropan2-ylamino)-4-methyl-1-oxopentan-2-ylamino)-5-benzyl-3-hydroxy-6-oxo-1-phenylhexan-2-ylcarbamate (L-685,458). Specific $\gamma$-secretase activity was obtained by subtracting nonspecific from total ECL signals. Photo-affinity labeling experiment was performed by incu- 
bating equivalent amounts of membrane protein from wild-type and PS1 $\Delta$ E10 mouse brains with 2 nM tert-butyl (14S,17S,20R,22R,23S)-14-(4benzoylbenzyl)-20-benzyl-22-hydroxy-17-isobutyl-5,13,16,19-tetraoxo-1-(2-oxohexahydro- $1 H$-thieno[3,4-d] imidazol-4-yl)-24-phenyl6,12,15,18-tetraazatetracosan-23-ylcarbamate (L-852,505), a photolabeled transition-state $\gamma$-secretase inhibitor, in either the presence or absence of $2 \mu \mathrm{M}$ nonlabeled L-685,458. The labeled samples were solubilized and isolated with immobilized streptavidin and analyzed using the anti-PS1-CTF antibody PS1C.

Sandwich ELISA. Sandwich ELISAs for quantifying human $\mathrm{A} \beta_{40}$ and $\mathrm{A} \beta_{42}$ were performed as described using $6 \mathrm{E} 10$ as the capture antibody and G2-10 and G2-11 as detection antibodies, which recognize $A \beta_{40}$ and $\mathrm{A} \beta_{42}$ specifically (Yan et al., 1999; Xia et al., 2002). Briefly, $4 \times$ TBS buffer $(\mathrm{v} / \mathrm{w})$ was used to homogenize brain samples, which were centrifuged at $8000 \times g$ for $1 \mathrm{~h}$. The supernatants were used for soluble $\mathrm{A} \beta$ measurement. The pellets were resuspended in $5 \mathrm{M}$ guanidine $(2 \times)$ and sonicated. Homogenate $(20 \mu \mathrm{l})$ was diluted with $10 \times$ loading buffer. After centrifugation at $8000 \times g$ for $30 \mathrm{~min}$, the samples were loaded into wells for $\mathrm{A} \beta$ peptides detection. A total of $100 \mu \mathrm{l}$ of $6 \mathrm{E} 10(4 \mu \mathrm{g} / \mathrm{ml})$ diluted in carbonate-bicarbonate buffer, $\mathrm{pH}$ 9.6, was added to coated microtiter plates and incubated at $4^{\circ} \mathrm{C}$ overnight. After washing plates with PBS containing $0.05 \%$ Tween-20 (PBST), plates were blocked for $1 \mathrm{~h}$ with 200 $\mu \mathrm{l}$ of PBST with $1 \%$ BSA. After washing the plate, $100 \mu \mathrm{l}$ of standards $\left(\mathrm{A} \beta_{1-40}\right.$ and $\mathrm{A} \beta_{1-42} ;$ Bachem, Torrance, $\left.\mathrm{CA}\right)$ was applied and incubated for $2 \mathrm{~h}$ at room temperature or $4^{\circ} \mathrm{C}$ overnight. After washing, plates were incubated with biotinylated G2-10 or G2-11 diluted 1:1000 and 1:500, respectively, in PBST at room temperature for $1 \mathrm{~h} 30 \mathrm{~min}$. After washing, neutravidin-horseradish peroxidase (Pierce) diluted 1:5000 in PBST was added and incubated $1 \mathrm{~h}$ at room temperature. After washing the plate three times, $100 \mu \mathrm{l} / \mathrm{ml}$ tetramethylbenzidine solution was added and incubated at $15-30 \mathrm{~min}$ at room temperature. The color development was stopped by adding $100 \mu \mathrm{l} /$ well stop solution ( $1 \mathrm{M}$ phosphoric acid). The optical density was measured at $490 \mathrm{~nm}$ by a microELISA reader. The concentrations of $\mathrm{A} \beta_{40}$ and $\mathrm{A} \beta_{42}$ were calculated from the linear range of the standard curve for each plate, respectively. Five forebrain samples per genotype were analyzed each in triplets.

Immunohistochemistry and amyloid load quantification. Mice were cardiac-perfused with PBS containing heparin and fixed with $4 \%$ paraformaldehyde at $4^{\circ} \mathrm{C}$ overnight. After dehydration and paraffin embedding, the brains were cut into $6 \mu \mathrm{m}$ sections. The sections were deparaffinized in xylene and then rinsed with 100, 95, and 70\% ethanol and water. Nonspecific epitopes were blocked for $1 \mathrm{~h}$ with $0.3 \mathrm{ml}$ of goat serum in PBS. Primary antibody 6E10 was diluted 1:1000 in PBS containing $1 \% \mathrm{BSA}$ and incubated overnight at $4^{\circ} \mathrm{C}$ in a humidified chamber. Sections were then washed three times for 5 min each in PBS and incubated with biotinylated anti-mouse secondary antibody, followed by incubation with biotinylated peroxidase-coupled avidin (Vectastain ABC kit; Vector Laboratories, Burlingame, CA). Pictures were taken with a Zeiss (Oberkochen, Germany) Axioskop 2 Plus microscope equipped with the Axiocam MRC digital camera, and the images were processed with the Axiovision 3.1 software. For thioflavine S staining, the paraffinembedded slices were incubated in $0.5 \%$ thioflavine S in PBS for $10 \mathrm{~min}$ in the dark. Fluorescent signals were visualized after decolorizing with $95 \%$ ethanol. For plaque quantification, four to six nonoverlapping and comparable coronal sections of midbrain area were selected from matched APP and APP/ $\Delta$ E10 mice ( $n=3$ per genotype per age). Visible plaques larger or equal to $5 \mu \mathrm{m}$ were counted manually under an Olympus Optical (Thornwood, NY) microscope (CX 31). The number of plaques in the left and right hemi-brains was counted separately two times each, and the average number was calculated. The total number of plaques for each genotype is expressed as the mean of all sections in the same age group of mice \pm SD.

\section{Results}

PS1 with deletion of exon 10 undergoes normal endoproteolytic processing and $\gamma$-secretase complex assembly

The mouse PS1 gene contains 12 exons with 3-12 as coding exons (GenBank accession number AF007560). It encodes a protein of
467 amino acids with eight putative TM domains (diagramed in Fig. 1A). Exon 10 of mouse PS1 encodes amino acids 320-377 downstream of the PS1 endoproteolytic cleavage site (Fig. $1 A$, arrow, position 292-293) and covers most of the hydrophilic loop sequences between TM 6 and 7 essential for PS1/ $\beta$-catenin association (Kang et al., 1999; Soriano et al., 2001). Deletion of exon 10 generates an in-frame downstream fusion protein and is expected to preserve the remaining membrane structures.

To create an exon 10 deletion of the endogenous mouse PS1, we inserted a neomycin-resistance gene (neo) containing the loxP sequence at the $5^{\prime}$ end of intron 9 and another loxP sequence in intron 10 (Fig. $1 B$ ) (supplemental Fig. S1, available at www. jneurosci.org as supplemental material). Gene targeting followed by Cre-recombinase (Cre)-mediated recombination in embryonic stem cells resulted in the deletion of exon 10 of the PS1 gene (PS1 $\Delta$ E10) (supplemental Fig. S1, available at www.jneurosci. org as supplemental material). Heterozygous exon 10-deleted mice $(P S 1 \Delta \mathrm{E} 10 /+)$ were intercrossed to yield mice that were WT, heterozygous, or homozygous (PS1 $\Delta$ E10/ $\Delta$ E10) for exon 10 deletion; the latter are herein referred to as PS1 $\Delta \mathrm{E} 10$ or $\Delta \mathrm{E} 10$.

Because exon 10 is downstream of the PS1 endoproteolysis site, deletion of exon 10 is not expected to disrupt this cleavage event. Indeed, Western blot analysis of brain tissues from PS1 $\Delta \mathrm{E} 10$ animals documented normal endoproteolytic processing, producing a normal NTF (PS1-NTF) and a truncated CTF of 10 $\mathrm{kDa}$ attributable to exon 10 deletion $(\triangle \mathrm{E} 10-\mathrm{CTF})$ (Fig. $1 C)$. Both wild-type and truncated CTFs could be detected in PS1 $\Delta \mathrm{E} 10 /+$ heterozygous mice, and they apparently were expressed in equal amounts (Fig. 1C). The expression and maturation of nicastrin was not affected (Fig. 1C). Gel filtration fractionation of brain lysates showed that, similar to WT, the processed PS1 fragments eluted and cofractionated with nicastrin and Pen2 in highmolecular-weight fractions (Fig. $2 A$ ). The majority of $\beta$-catenin coeluted with the PS1 complex, whereas GSK $3 \beta$ and CDK5 predominately resided in low-molecular-weight fractions (Fig. $2 A$ ). No significant changes could be detected between wild-type and PS1 $\triangle \mathrm{E} 10$ samples. Photo-affinity labeling using the transitionstate $\gamma$-secretase inhibitor L-852,505, which only binds to active $\gamma$-secretase ( $\mathrm{Li}$ et al., 2000b), labeled both wild-type and $\Delta \mathrm{E} 10$ CTF, and this binding could be titrated away by a 100-fold excess of nonlabeled inhibitor L-685,458 (Fig. 2B). These results reveal normal PS1 processing and high-molecular-weight and active $\gamma$-secretase complex assembly in the absence of the PS1 hydrophilic loop sequence within our assay detection limits.

\section{Disruption of $\boldsymbol{\beta}$-catenin interaction but no spontaneous skin tumor development in PS1 $\triangle \mathrm{E} 10$ mice}

IP followed by Western blot analysis showed that, in the wildtype control, PS1N antibody could pull down both endogenous $\mathrm{N}$-cadherin and $\beta$-catenin (Fig. 3), confirming the interaction of PS1 with the two proteins. However, the same PS1N antibody failed to immunoprecipitate $\mathrm{N}$-cadherin or $\beta$-catenin in PS1 $\Delta$ E10 samples (Fig. 3 ). These data demonstrate that $\beta$-catenin and $\mathrm{N}$-cadherin interact with PS1 through the hydrophilic loop domain in vivo and that this interaction is disrupted in the PS1 $\Delta \mathrm{E} 10$ mutant. Consistent with the predominant plasma membrane localization of $\beta$-catenin and $\mathrm{N}$-cadherin, the amount of both proteins that associate with PS1 was low compared with the total lysate (Fig. 3, compare Lysate with IP). Similar to the wildtype control, in the PS1 $\Delta$ E10 mutant, the PS1N antibody pulled down $\triangle \mathrm{E} 10-\mathrm{CTF}$ as well as all known essential components of the $\gamma$-secretase complex, including nicastrin, Aph1, and Pen2 (Fig. 3 ). This result is consistent with our gel filtration and photo- 
A

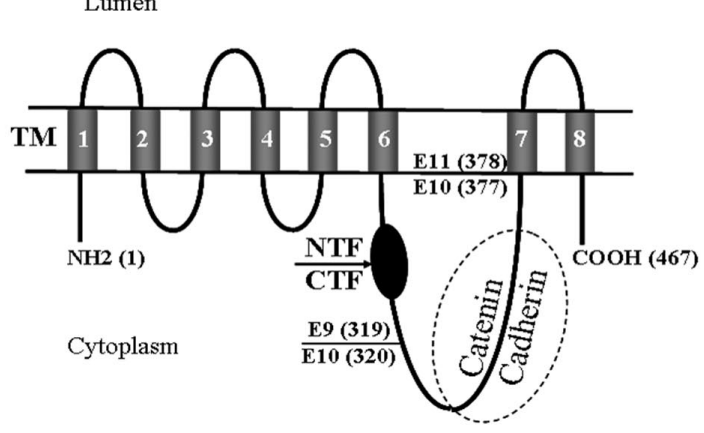

B
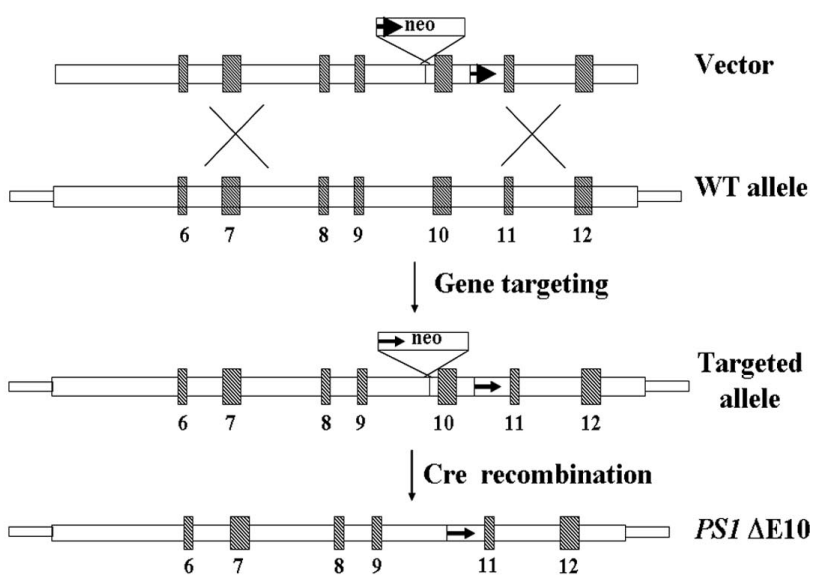

C

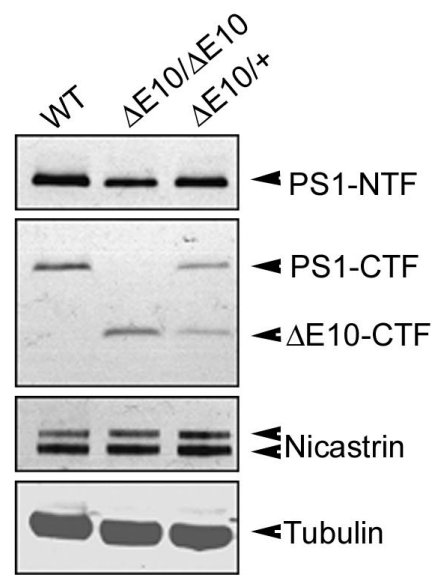

Figure 1. Generation and biochemical characterization of $P S 1 \triangle E 10$ mice. $A$, Diagram showing PS1 secondary structure, PS1 endoproteolytic cleavage site (arrow), exon 9 (E9)/E10 and E10/E11 boundaries, and region of PS1/ $\beta$-catenin and PS1/cadherin interaction. Numbers in parentheses mark the number of amino acids in the PS1 protein. The solid oval represents the hydrophobic domain in which PS1 endoproteolytic processing takes place, which produces an NTF and a CTF. $\boldsymbol{B}$, Scheme for creating the PS1 $\triangle$ E10 allele. Homologous recombination between the targeting vector and wild-type PS1 introduces the neo gene and two loxP sites flanking the neo and exon 10 of PS1 (targeted allele). Cre-mediated recombination subsequently deletes the neo and exon 10 sequences, leaving a 34 bp loxP site in the intron (PS1 $\Delta$ E10 allele). For detailed description and characterization, please refer to supplemental Methods and Figure S1 (available at www.jneurosci.org as supplemental material). C, Expression profiles of PS1 in wild-type and PS1 $\Delta \mathrm{E} 10$ heterozygous $(\Delta \mathrm{E} 10 /+)$ and homozygous $(\Delta \mathrm{E} 10 / \Delta \mathrm{E} 10)$ mice. Western blotting using the anti-PS1N antibody detected normally processed PS1-NTF in all three genotypes. Whereas the anti-PS1C antibody recognized a product at $18 \mathrm{kDa}$ (PS1-CTF), a truncated fragment at $10 \mathrm{kDa}$ ( $\Delta \mathrm{E} 10-\mathrm{CTF})$, representing the exon 10-deleted product, was detected in heterozygous $(\Delta \mathrm{E} 10 /+)$ and homozygous $(\Delta \mathrm{E} 10 / \Delta \mathrm{E} 10)$ samples, respectively. Nicastrin and $\alpha$-tubulin were also analyzed, which documented normal expression of nicastrin and equal loading.
A

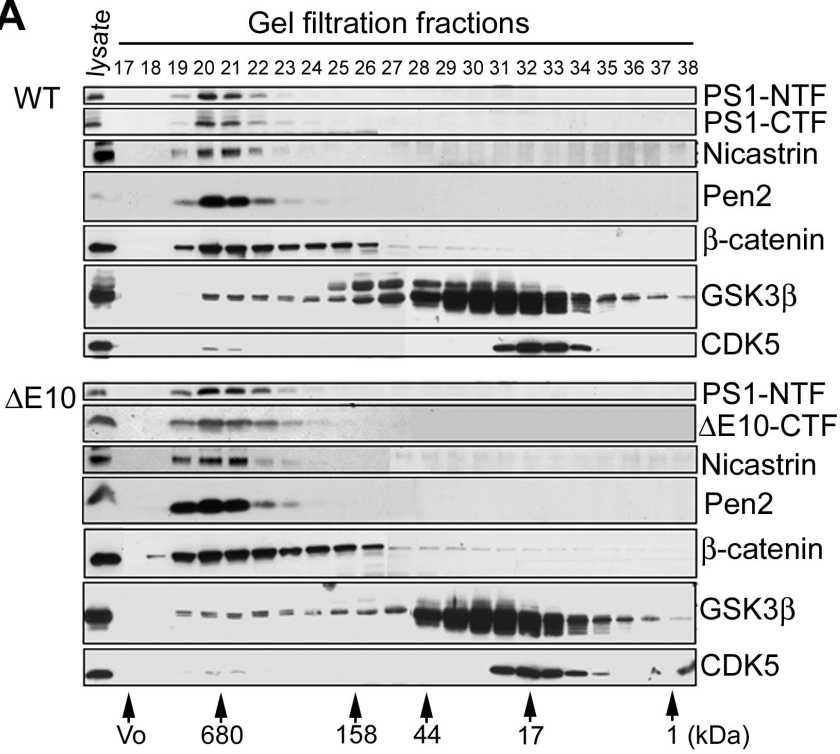

B

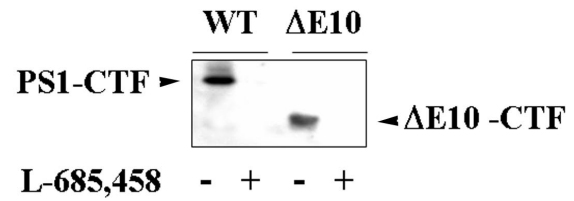

Figure 2. Biochemical characterization of PS1 $\triangle E 10$ mutants. Gel filtration chromatography fractionation of WT and PS1 $\Delta$ E10 mouse brain samples. Forebrain tissues dissected from the two strains of the animals were lysed in $1 \%$ digitonin lysis buffer. Two milligrams of brain lysates from the WT and $\Delta$ E10 mice were subjected to Bio-Sil SEC250 - 5 HPLC column (BioRad) fractionation, respectively. A total of $40 \mu \mathrm{l}$ of each eluted fraction were analyzed by Western blotting using the anti-PS1N, PS1C, nicastrin, Pen2, $\beta$-catenin, GSK3 $\beta$, and Cdk5 antibodies. The molecular weight (in kilodaltons) of gel filtration fractions was determined by fractionation of blue dextran ( $V_{0}$ ) and the gel filtration standards under the same conditions. $\boldsymbol{B}$, Photo-affinity labeling of WT and $\Delta$ E10 brains with an active, site-directed $\gamma$-secretase inhibitor. Equivalent amount of membrane proteins from both brain lysates were photo-labeled with $\mathrm{L}-852,505$, a transition-state $\boldsymbol{\gamma}$-secretase inhibitor. The labeled samples were solubilized, isolated with immobilized streptavidin, and Western blotted with the anti-PS1-CTF antibody. - , Absence of nonlabeled inhibitor L-685,458; + , presence of 100-fold excess of L-685,458.

labeling data (Fig. 2) and provides further demonstration for the normal assembly of the $\gamma$-secretase complex in PS1 $\Delta \mathrm{E} 10$ mutants.

The PS1 $\triangle \mathrm{E} 10$ mice were viable, fertile, and overtly healthy for up to 2 years of age. Immunofluorescence staining using presynaptic and postsynaptic markers did not identify abnormalities in PS1 $\triangle \mathrm{E} 10$ brains, nor could we detect differences in the expression or cellular localization of $\beta$-catenin or $\mathrm{N}$-cadherin in the mutant (data not shown). In contrast to our PS1 rescue mice (Xia et al., 2001), no epidermal hyperplasia or skin tumor phenotypes could be identified in these animals. Western blot analysis failed to reveal significant alterations of soluble $\beta$-catenin or cyclin D1 in the skin (data not shown). These findings do not support a major contribution of PS1/ $\beta$-catenin or PS1/cadherin interactions in regulating $\beta$-catenin or cadherin homeostasis but rather suggest that indirect regulation of $\beta$-catenin by PS1 downstream of Notch may be the predominant pathway in vivo (Nicolas et al., 2003).

Evidence for the lack of PS1 homodimers in $\gamma$-secretase complex

It has been reported that presenilins form homodimers at the core of the $\gamma$-secretase complex and that the transmembrane do- 


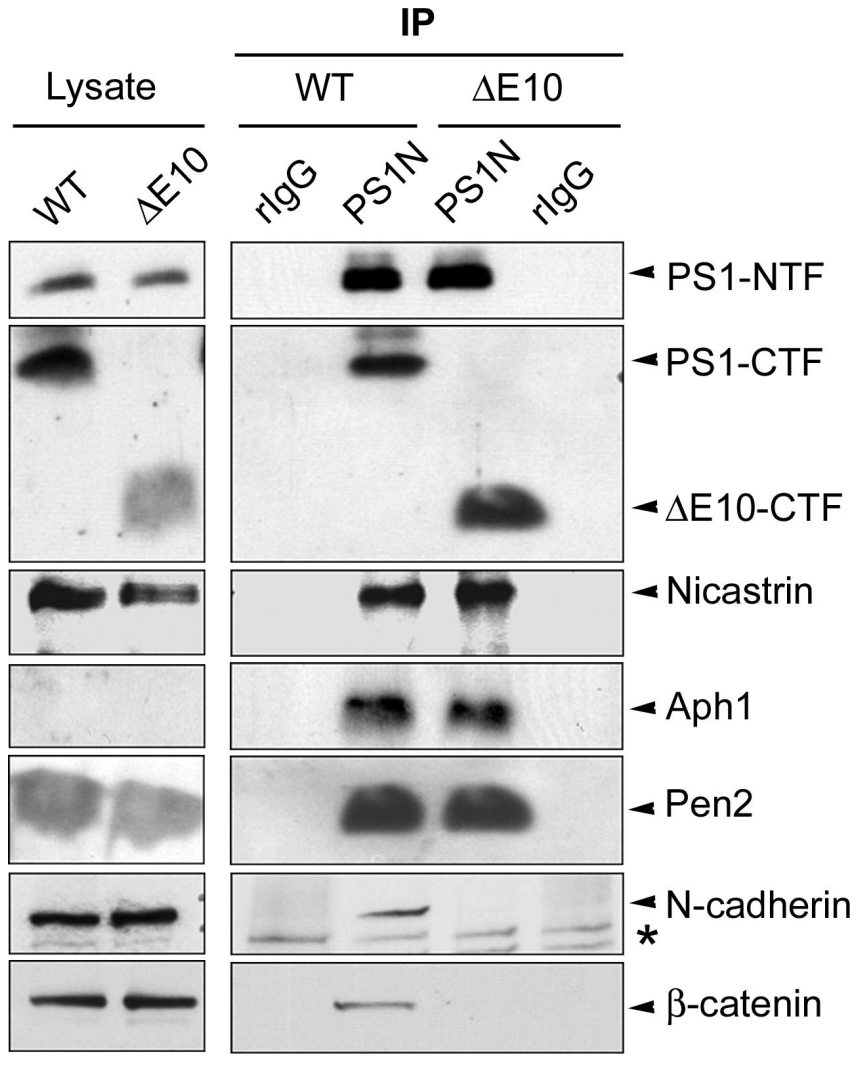

Figure 3. Exon 10 deletion abolishes PS1 association with $\beta$-catenin and N-cadherin. Brain extracts of WT or PS1 $\triangle$ E10 mice in $1 \%$ digitonin were immunoprecipitated by disuccinimidyl suberate cross-linked PS1N antibodies or control rabbit lgG (rlgG), respectively, and the resulting immunoprecipitates were probed on Western blots with indicated antibodies. In both WT and $\Delta$ E10 samples, PS1-NTF, PS1-CTF, $\Delta$ E10-CTF, nicastrin, Aph1, and Pen2 coimmunoprecipitated with the PS1N antibody. N-Cadherin and $\beta$-catenin coimmunoprecipitated with PS1N in WT mice but not in $\Delta \mathrm{E} 10$ mice. Lysate, Total brain lysate at $50 \mu \mathrm{g}$. Aph 1 cannot be seen by straight Western blot because of the sensitivity of the antibody but can be detected by IPWestern blot. The asterisk denotes nonspecific hybridization.

mains are essential for dimer formation (Schroeter et al., 2003; Cervantes et al., 2004). Mice heterozygous for the PS1 $\Delta \mathrm{E} 10$ allele $(P S 1 \Delta \mathrm{E} 10 /+)$ provide a unique system to investigate this further because the wild-type PS1-CTF and $\Delta \mathrm{E} 10-\mathrm{CTF}$ are expressed at an equal molar ratio and these two fragments can be distinguished on Western blots. We reasoned that, if a dimer complex model is true, the wild-type PS1-CTF should coimmunoprecipitate with $\Delta \mathrm{E} 10-\mathrm{CTF}$ either via direct interaction or indirectly through other proteins in the complex, for example, PS1-NTF. Immunoprecipitation with PS1N antibody pulled down both wild-type PS1-CTF and $\triangle \mathrm{E} 10-\mathrm{CTF}$ at similar efficiencies (Fig. $4 A$ ), indicating that there was no differential interaction of PS1NTF with the two CTFs. We next performed IP using a monoclonal PS1 loop antibody that only recognizes the wild-type PS1CTF because the epitope is lost in $\triangle \mathrm{E} 10$-CTF. Western blot analysis showed that the loop antibody immunoprecipitated PS1-NTF, PS1-CTF, and nicastrin in a dose-dependent manner. However, there was no $\Delta \mathrm{E} 10-\mathrm{CTF}$ in the complex (Fig. $4 B$ ). These results thus argue against the existence of PS1 homodimers in the $\gamma$-secretase complex.

\section{The PS1 hydrophilic loop modulates $\gamma$-secretase activity}

Although the hydrophilic loop sequence of PS1 has been shown to be dispensable for $\gamma$-secretase activity (Saura et al., 2000; Xia et al., 2002), the assays used do not quantitatively address whether
A
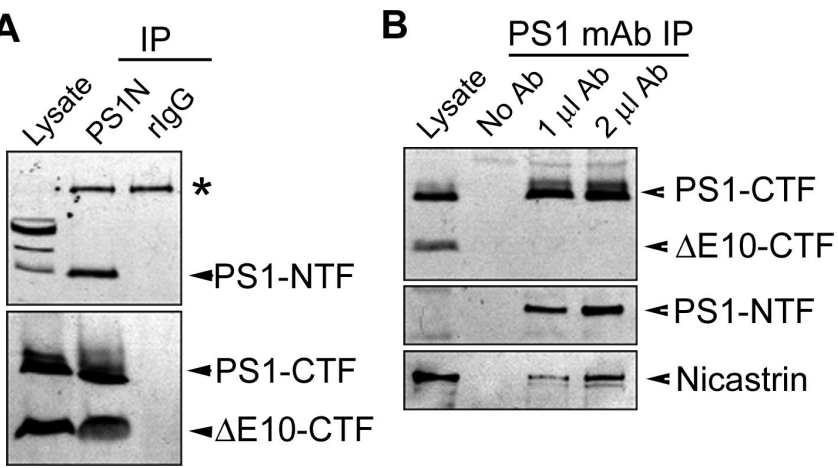

Figure 4. PS1-CTF and $\Delta \mathrm{E} 10-\mathrm{CTF}$ do not form dimers. PS1 $\Delta \mathrm{E} 10 /+$ heterozygous mouse brain was used to analyze the dimer formation between the PS1 fragments. $A, \Delta \mathrm{E} 10 /+$ brain lysates (Lysate) were subjected to immunoprecipitation with the PS1N antibody, followed by Western blotting using the PS1N and PS1C antibodies, respectively. The result showed positive interaction of PS1-NTF with wild-type (PS1-CTF) and $\Delta$ E10-CTF and that the PS1C antibody recognized both CTFs with similar affinity. rlgG, IP with rabbit lgG antibody. The asterisk denotes nonspecific hybridization. $\boldsymbol{B}$, Forebrain extracts in $1 \%$ CHAPSO were immunoprecipitated by a monoclonal anti-PS1 loop antibody (PS1mAb), which only recognizes wild-type PS1-CTF, but not $\Delta$ E10-CTF, at 1 and $2 \mu$ l concentrations, followed by Western blotting using the PS1C, PS1N, and anti-nicastrin antibodies. The results documented coimmunoprecipitation of PS1CTF with PS1-NTF and nicastrin. However, PS1-CTF and $\Delta$ E10-CTF did not coimmunoprecipitate. Lysate, Total brain lysate at $50 \mu \mathrm{g}$ showing the presence of both PS1-CTF and $\Delta$ E10-CTF in the input. Ab, Antibody.

this domain plays a regulatory role. We therefore examined the effect of exon 10 deletion on $\gamma$-secretase activity and $\mathrm{A} \beta$ production using both an in vitro cleavage assay and a cell-based sandwich ELISA (Li et al., 2000a,b; Tarassishin et al., 2004). To accurately determine the effect of the PS1 loop sequence on $\gamma$-secretase activity, various amounts of membrane proteins from the wild-type and PS1 $\Delta \mathrm{E} 10$ mouse brains were incubated with the substrate, and the rate of $\gamma$-secretase-dependent $A \beta_{40}$ and $\mathrm{A} \beta_{42}$ production was measured (Fig. $5 A$ ). Compared with the WT samples, the production of $\mathrm{A} \beta_{40}$ was significantly reduced, whereas the $\mathrm{A} \beta_{42}$ activity was only marginally decreased in PS1 $\triangle \mathrm{E} 10$ mouse brains (Fig. $5 A$ ). This differential impact on $\mathrm{A} \beta_{40}$ and $\mathrm{A} \beta_{42}$ production led to a 1.7 -fold increase in the ratio of $\mathrm{A} \beta_{42} / \mathrm{A} \beta_{40}$ in the exon 10 deletion mutant (wild-type, 0.25; PS1 $\Delta \mathrm{E} 10,0.43)$. Similar effects on $\mathrm{A} \beta_{40}$ and $\mathrm{A} \beta_{42}$ production were also observed using cell membranes as a source of $\gamma$-secretase (data not shown). To further substantiate this finding, we crossed the PS1 $\triangle \mathrm{E} 10$ homozygous mice with the Tg2576 strain of APP transgenic mice (Hsiao et al., 1996) to obtain animals expressing $A P P$ on either wild-type PS1 (APP) or PS1 $\triangle \mathrm{E} 10$ homozygous background (APP/ $\triangle \mathrm{E} 10)$ and measured human $\mathrm{A} \beta_{40}$ and $\mathrm{A} \beta_{42}$ levels using a cell-based sandwich ELISA assay at 2 months of age (Xia et al., 2002). The data again documented a differential reduction in $\mathrm{A} \beta_{40}$ without significantly changing $\mathrm{A} \beta_{42}$ in both soluble and insoluble fractions of $\mathrm{APP} / \Delta \mathrm{E} 10$ brains (Fig. $5 B$ ). The smaller degree of reduction of $A \beta_{40}$ measured by sandwich ELISA compared with the in vitro enzymatic assay could be caused by differences of the detection systems or by the ectopic overexpression of $A P P$ in $\mathrm{APP} / \triangle \mathrm{E} 10$ animals. Overall, results from both assays demonstrate substantial reduction of $\mathrm{A} \beta_{40}$, but not $\mathrm{A} \beta 42$, production and significant increase in the ratio of $A \beta_{42} / A \beta_{40}$ as a result of PS1 exon 10 deletion.

Extracellular processing of APP by $\alpha$ - or $\beta$-secretases generates APP-CTFs, which serve as substrates for $\gamma$-secretase cleavage. Therefore, although $\mathrm{A} \beta_{40}$ and $\mathrm{A} \beta_{42}$ are measurements of specific $\gamma$-secretase products, levels of APP-CTF, which result from in- 
A

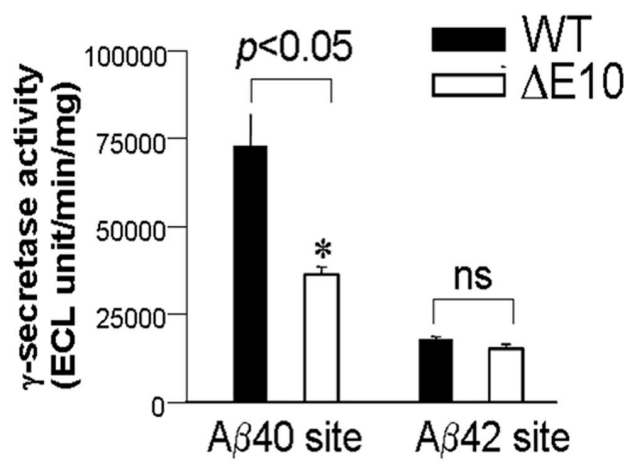

B

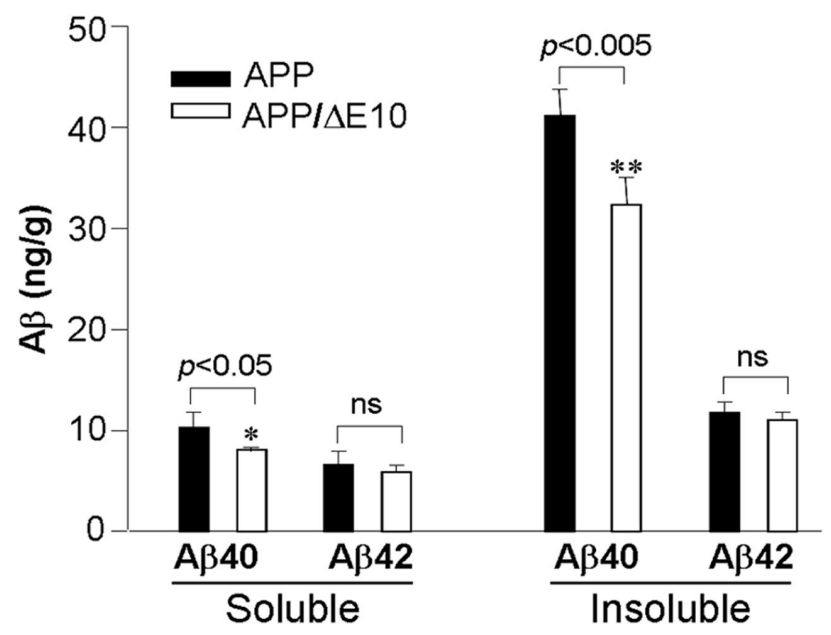

Figure 5. Effect of $P S 1 \Delta \mathrm{E} 10$ on $\mathrm{A} \beta_{40}$ and $\mathrm{A} \beta_{42}$ production. $\boldsymbol{A}$, In vitro $\gamma$-secretase assay to determine the reaction rate of $\gamma$-secretase for the 40 and 42 site cleavage. The CHAPSOsolubilized membrane proteins prepared from the WT and PS1 $\Delta \mathrm{E} 10$ mouse brain samples were used for the in vitro $\gamma$-secretase activity assay. The 40 and 42 site cleavages were detected by G2-10 and G2-11 antibodies, respectively. $n=3$ per group. $B$, Sandwich ELISA of human $A \beta_{40}$ and $A \beta_{42}$ in forebrain samples of Tg2576 APP transgenic mice (APP) or APP transgene expressed on homozygous PS1 $\Delta \mathrm{E} 10$ background (APP/ $\Delta \mathrm{E} 10)$. Soluble, TBS soluble $A \beta$; Insoluble, TBS-resistant, guanidine-extractable $A \beta$. Mice at 2 months of age were used for both assays. Student's $t$ test was used for all statistical analysis, and the $p$ values are shown. ns, Nonsignificant ( $p>0.05, t$ test).

sufficient PS-dependent processing, inversely correlate with total $\gamma$-secretase activity. Having established an impaired $\mathrm{A} \beta_{40}$ production in PS1 $\triangle$ E10 animals, we next determined the effect of the loop deletion on overall PS1-dependent processing. Western blot analysis of brain samples taken from APP transgenic mice expressing either wild-type PS1 (APP) or PS1 with exon 10 deletion (APP/ $\triangle \mathrm{E} 10)$ showed that both the APP-CTF levels (Fig. 6A) as well as the CTF to full-length ratio (Fig. $6 B$ ) were significantly higher in APP/ $\triangle \mathrm{E} 10$ samples than the APP controls. The same result was also obtained when another PS1 substrate N-cadherin was analyzed (Fig. 6). These data support the notion that the PS1 $\Delta \mathrm{E} 10$ is partial loss-of-function on $\gamma$-secretase activity, leading to the accumulations of APP and N-cadherin CTF. Because APPCTF intensities inversely correlate with $\mathrm{A} \beta_{40}$ levels, it is thus the level of $\mathrm{A} \beta_{40}$, but not $\mathrm{A} \beta_{42}$, that is representative of the total $\gamma$-secretase activity.

\section{Exacerbated plaque pathology in PS1 $\triangle \mathrm{E} 10$ mice}

$\mathrm{A} \beta_{42}$ has been established to play a dominant role in amyloid pathology (Iwatsubo et al., 1994; McGowan et al., 2005). However, $\mathrm{A} \beta_{40}$ is the major $\mathrm{A} \beta$ species produced, and its contribution
A

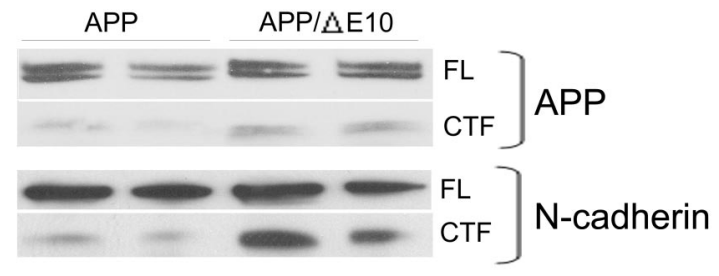

B

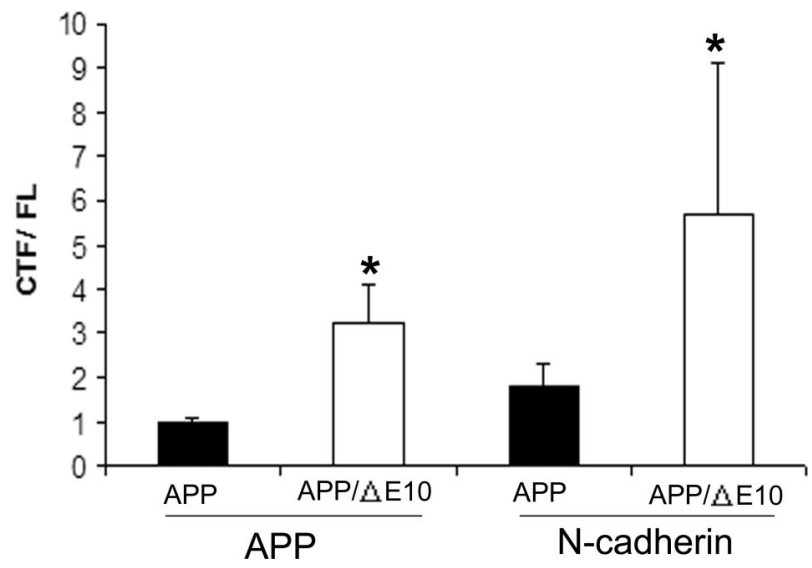

Figure 6. Western blot analysis of APP and N-cadherin CTF levels. $\boldsymbol{A}$, Representative Western blots of full-length (FL) APP and N-cadherin and their perspective (TF levels in forebrains of 12-month-old Tg2576 APP transgenic mice (APP) or APP transgene expressed on homozygous PS1 $\Delta$ E10 background (APP/ $\Delta$ E10). $\boldsymbol{B}$, Normalized APP and N-cadherin CTF to full-length ratio (mean $\pm \mathrm{SD}) .{ }^{*} p<0.05$ (Student's $t$ test).

to amyloid pathogenesis has not been clearly defined because PS1 familial $\mathrm{AD}(\mathrm{FAD})$ mutations often result in a shift of cleavage from the $\mathrm{A} \beta_{40}$ site to the $\mathrm{A} \beta_{42}$ site. The fact that deletion of the PS1 hydrophilic loop sequence leads to a specific reduction of $\mathrm{A} \beta_{40}$ without alteration in $\mathrm{A} \beta_{42}$ offers a unique system to determine the effect of $\mathrm{A} \beta_{40}$ on amyloid pathology. We therefore performed $\mathrm{A} \beta$ immunohistochemical staining to evaluate the $\beta$-amyloid plaque pathology in APP/ $\Delta \mathrm{E} 10$ mice and compared it with APP transgenic controls. Females were used for all studies to eliminate potential variability caused by gender differences.

We performed $\mathrm{A} \beta$ staining of 10 -month-old animals because this age marks the onset of amyloid pathology in APP transgenic mice. As expected, sparse amyloid deposits could be detected only in the cortex (Fig. 7Aa, arrowhead), but not the hippocampus (Fig. 7Ac), of control APP mice. Because APP/ $\Delta$ E10 samples exhibited reduced $\gamma$-secretase activity, we expected delayed onset of plaque pathology in these animals. Surprisingly, the plaque density was dramatically higher in $\mathrm{APP} / \Delta \mathrm{E} 10$ brains, and numerous plaques could be detected in both the cortex and hippocampus at this age (Fig. 7Ab, $A d$, arrowheads, respectively; quantified in $C$ ). Analysis of 12-month-old animals revealed limited plaques in the cortex and hippocampus of APP controls (Fig. 7Ba), and thioflavine S-positive plaques were minimal (Fig. $7 B c$ ). In contrast, the plaque pathology was significantly enhanced in both the cortex and hippocampus of $\mathrm{APP} / \Delta \mathrm{E} 10$ brains (Fig. $7 \mathrm{Bb}$; quantified in $C$ ), and most of the plaques were thioflavine $S$ positive (Fig. $7 B d$ ). Similar results were obtained when the two transgenic lines were compared at 14 and 16 months, which showed an approximate threefold increase in plaque density in $\mathrm{APP} / \Delta \mathrm{E} 10$ brains compared with that of APP transgenic controls (Fig. $7 C$ ). 
A
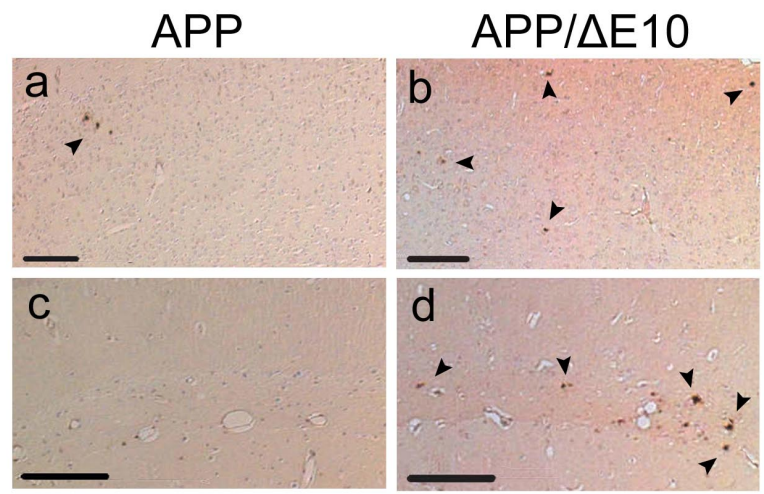

B
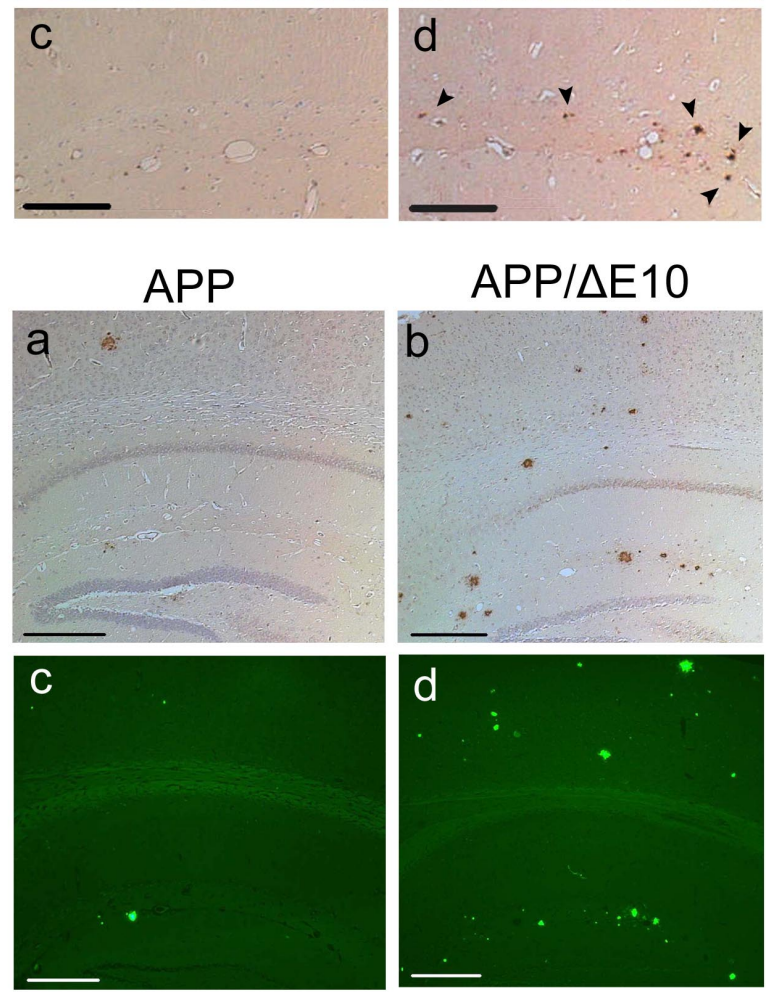

C

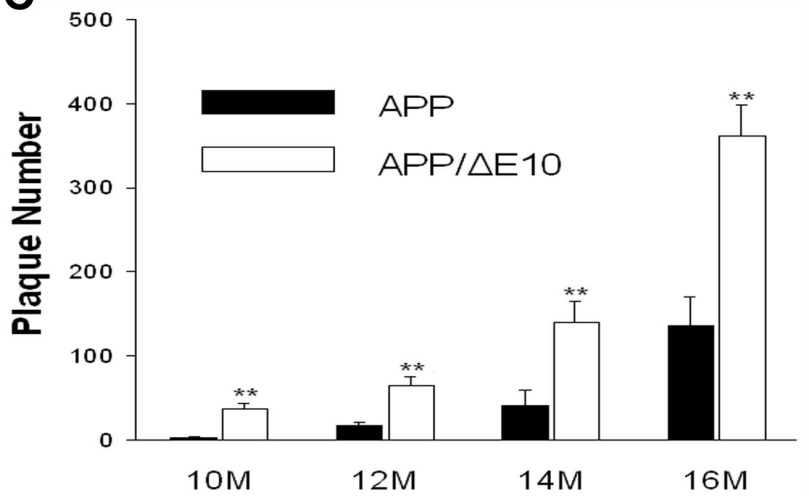

Figure 7. Deletion of the hydrophilic loop region of PS1 promotes amyloid plaque pathology. $\boldsymbol{A}$, Coronal sections of 10-month-old APP transgenic mice expressed on wild-type PS1 background (APP) or homozygous PS1 $\triangle \mathrm{E} 10$ background (APP/DE10) were immunostained with the $A \beta$ monoclonal antibody $6 \mathrm{E} 10$ and counterstained with hematoxylin. $\boldsymbol{a}, \boldsymbol{b}$, Cortex; $\boldsymbol{c}, \boldsymbol{d}$, hippocampus. Representative plaques are highlighted by arrowheads. $\boldsymbol{B}, 6 \mathrm{E} 10(\boldsymbol{a}, \boldsymbol{b})$ and thioflavine $S(\boldsymbol{c}, \boldsymbol{d})$ staining of APP and APP/DE10 animals at 12 months of age. Scale bars: $\boldsymbol{A}, 100$ $\mu \mathrm{m} ; \boldsymbol{B}, 200 \mu \mathrm{m}$. C, Quantification of the number of amyloid plaques in control APP and APP/ $\Delta$ E10 mice at $10,12,14$, and 16 months of age (M) (mean \pm SD). ${ }^{* *} p<0.001$ (Student's $t$ test).

Immunostaining of mice at 6-8 months failed to identify amyloid plaques in both the APP and APP/ $\Delta \mathrm{E} 10$ mice (data not shown), suggesting that the onset of plaque pathology was not significantly accelerated in $\mathrm{APP} / \Delta \mathrm{E} 10$ mutants. Overall, these results demonstrate that deletion of the PS1 hydrophilic loop do- main is associated with reduced $\mathrm{A} \beta_{40}$ production as well as total PS1-dependent processing, leading to exacerbated amyloid pathology without overtly affecting the onset of plaque deposition.

\section{Discussion}

Role of PS1 in $\beta$-catenin regulation and skin tumorigenesis PS1 interacts with $\beta$-catenin through the large hydrophilic loop domain, and substantial in vitro evidence supports an involvement of PS1 in $\beta$-catenin regulation through physical interactions (Kang et al., 1999; Soriano et al., 2001; Kang et al., 2002). This is corroborated by our in vivo findings that loss of PS1 is associated with skin tumorigenesis and an elevated signaling pool of $\beta$-catenin (Xia et al., 2001). However, PS1 deficiency simultaneously disrupts the Notch signaling pathway, and inactivation of Notch in epidermis has been shown to lead to $\beta$-catenin deregulation and skin tumor progression (Nicolas et al., 2003). As such, it remains to be established which of the two mechanisms plays a major role in $\beta$-catenin regulation in vivo. By creating mice with a deletion of exon 10 in endogenous PS1, we effectively removed the sequences required for $\beta$-catenin binding but preserved the $\gamma$-secretase complex essential for Notch processing. We document that mice with a homozygous deletion of exon 10 of PS1 do not exhibit overt abnormalities and do not develop spontaneous skin cancers. Therefore, the skin tumor phenotype seen in the absence of PS1 is likely caused by a defective Notch signaling pathway, with $\beta$-catenin as a downstream effector (Xia et al., 2001; Nicolas et al., 2003). This assessment is supported by our finding that PS2, which is known to contribute to Notch signaling but not $\beta$-catenin binding (Donoviel et al., 1999; Herreman et al., 1999; Kang et al., 1999), also facilitates hyperproliferative skin and other phenotypes (Qyang et al., 2004; Tournoy et al., 2004). Nevertheless, spontaneous skin tumor frequency in our PS1 "null" mice appears to be higher than that of the Notch 1 conditional knock-out, and a chemical-induced carcinogenesis protocol was used to substantiate a role of Notch 1 in skin tumorigenesis (Nicolas et al., 2003). Whether our PS1 $\Delta \mathrm{E} 10$ mice are more susceptible to carcinogen-induced tumor progression awaits future investigation.

In addition to $\beta$-catenin, the hydrophilic loop sequence of PS1 has been shown to interact with other proteins, including $\mathrm{N}$ - and E-cadherins, and this interaction has been reported to promote the cytoskeletal association of cadherin/catenin complexes at the synaptic and epithelial cell-cell contacts (Baki et al., 2001). The fact that deletion of exon 10 of PS1 disrupts the PS1-N-cadherin interaction without overtly affecting $\mathrm{N}$-cadherin expression or localization suggests that this interaction does not play a major role in regulating cadherin/catenin complex assembly or stability; the latter could be conferred through the PS1 $\gamma$-secretase activity because the cadherins have been shown to be subject to $\gamma$-secretase processing (Fig. 6) (Marambaud et al., 2002).

\section{Role of the PS1 hydrophilic loop in high-molecular-weight} complex assembly and $\gamma$-secretase activity

The hydrophilic loop sequences of PS1 and PS2 are not conserved, and previous studies demonstrated a dispensable role of the PS1 hydrophilic loop in $\gamma$-secretase function (Saura et al., 2000; Xia et al., 2002). However, taking into consideration that the PS1 FAD mutations spread throughout the entire protein including the loop sequence (summarized in http://www. alzforum.org) and that all mutations alter the $\gamma$-secretase processing profile, we rationalized that the PS1 hydrophilic loop sequence may play a modulatory role on $\gamma$-secretase cleavage. Indeed, both the in vitro $\gamma$-secretase assay and sandwich ELISA 
document a significant reduction of total $\mathrm{A} \beta\left(\mathrm{A} \beta_{40}\right.$ and $\left.\mathrm{A} \beta_{42}\right)$ and $A \beta_{40}$, and Western blot analysis reveals impaired PS1dependent processing as evidenced by higher APP and $\mathrm{N}$-cadherin CTF levels as a result of PS1 hydrophilic deletion. As such, the PS1 $\triangle \mathrm{E} 10$ allele represents a partial loss-of-function allele for the $\gamma$-secretase activity.

The mechanism for $\gamma$-secretase regulation by the PS1 loop domain remains to be established. Gel filtration analysis revealed normal formation of the high-molecular-weight complex in PS1 $\triangle \mathrm{E} 10$ brains. Because both point mutations and exon 9 deletion of PS1 FAD variants have been shown to lead to changes of PS1 conformation and substrate recognition (Berezovska et al., 2005), it is conceivable that deleting the large hydrophilic loop domain may also alter PS1 conformation and, hence, affect the $\gamma$-secretase activity. In particular, the loop domain, which bridges TM 6 and 7 in which aspartates 257 and 385 reside, could regulate the physical proximity of the two proposed active sites (Wolfe et al., 1999; Li et al., 2000b). Alternatively, the PS1 hydrophilic loop sequence has been reported to bind to numerous proteins in addition to $\beta$-catenin and has been shown to be phosphorylated by GSK3 $\beta$ (Thinakaran, 1999; Kirschenbaum et al., 2001). The loop domain could in principle affect the $\gamma$-secretase assembly and activity through these interacting proteins or posttranslational modifications. Indeed, $\gamma$-secretase complexes of various molecular mass and activities have been reported, and $\beta$-catenin was shown to be a component of the complex (Yu et al., 1998; Gu et al., 2004). Of additional note, $\mathrm{Wu}$ et al. (1998) showed that the Caenorhabditis elegans presenilin Sel12 physically interacts with Sel10 through the hydrophilic loop. Sel10 is a homolog of the mammalian ubiquitin ligase Fbw9 that has been implicated in facilitation of the ubiquitination of cyclin $\mathrm{E}$ and Notch (Gupta-Rossi et al., 2001; Koepp et al., 2001; Tetzlaff et al., 2004). Therefore, it is tempting to speculate that interaction of PS1 with Fbw9 could regulate PS1 stability and, by extension, $\gamma$-secretase activity. However, we did not detect significant changes in PS1 turnover rate in fibroblast or neuronal cultures derived from PS1 $\triangle \mathrm{E} 10$ mice, nor could we find any differences in PS1 protein levels by Fbw9 interference RNA treatment (Y. Deng and $\mathrm{H}$. Zheng, unpublished observation). Therefore, activated Notch as a result of Fbw9 inactivation is likely caused by a presenilin-independent mechanism.

The expression of two biochemically differentiable PS1 CTFs at an equal molar ratio in the PS1 $\triangle \mathrm{E} 10$ heterozygous mice offers a distinct advantage to test the PS1 homodimer model (Schroeter et al., 2003; Cervantes et al., 2004). Our results that both the wild-type PS1-CTF and $\triangle \mathrm{E} 10-\mathrm{CTF}$ (1) could be incorporated into a similar high-molecular-weight complex (Fig. 2A), (2) could complex with PS1-NTF as well as all other known essential $\gamma$-secretase components, including nicastrin, Aph1 and Pen2 (Fig. 3), and (3) could be specifically labeled by a transition-state inhibitor that only binds to active $\gamma$-secretase complex (Fig. $2 B$ ) provide strong support for the notion that deletion of exon 10 does not interfere with $\gamma$-secretase assembly. The fact that wildtype PS1-CTF and $\triangle \mathrm{E} 10-\mathrm{CTF}$ do not interact with each other thus argues against the existence of PS1 homodimers in the $\gamma$-secretase complex. This assessment is in line with the finding by Saura et al. (1999) that PS1 and PS2 fragments do not assemble into the same complex, although they individually recruit the same $\gamma$-secretase cofactors. However, we cannot exclude the possibility that the wild-type PS1 and PS1 $\Delta$ E10 form independent homodimers.

\section{Partial loss-of-function is the underlying mechanism for enhanced amyloid pathology in PS1 $\triangle \mathrm{E} 10$ mice}

Immunohistochemical analysis showed that deletion of the PS1 hydrophilic loop sequence resulted in a 2.5- to 3-fold increase in amyloid burden. Because these animals exhibit reduced $\mathrm{A} \beta_{40}$ levels, whereas $\mathrm{A} \beta_{42}$ remains constant, the exacerbated plaque pathology in $\mathrm{APP} / \Delta \mathrm{E} 10$ mice is likely the outcome of partial lossof-function at $\mathrm{A} \beta_{40}$ site cleavage. This is, to our knowledge, the first report to demonstrate that a net reduction of $\gamma$-secretase activity can promote amyloid pathology, and our results suggest that $\mathrm{A} \beta_{40}$ is protective against amyloidogenesis. Because the onset of plaque pathology is not significantly affected by the loop deletion, it appears that $\mathrm{A} \beta_{42}$ plays an essential role in initiating the amyloid pathology, whereas $\mathrm{A} \beta_{40}$ negatively affects the severity. A dominant effect of $\mathrm{A} \beta_{42}$ on amyloid pathogenesis was demonstrated recently by McGowan et al. (2005) who showed plaque formation in transgenic mice expressing $\mathrm{A} \beta_{42}$ alone but not $\mathrm{A} \beta_{40}$.

Our finding that partial loss-of-function of $\gamma$-secretase activity can promote amyloid pathology has important implications in our understanding of PS1 FAD mutations and AD pathogenesis in general. Because both PS1 $\triangle \mathrm{E} 10$ and PS1 FAD variants lead to an increased ratio of $\mathrm{A} \beta_{42} / \mathrm{A} \beta_{40}$ and accelerated plaque pathology, it can be argued that they share common mechanisms in the amyloidogenic process. The increase in $\mathrm{A} \beta_{42} / \mathrm{A} \beta_{40}$ ratio in PS1 $\triangle \mathrm{E} 10$ mice is caused solely by reduced $\mathrm{A} \beta_{40}$, whereas in the case of PS1 FAD, it is often attributed by a simultaneous increase in $\mathrm{A} \beta_{42}$ and reduction in $\mathrm{A} \beta_{40}$ (Kulic et al., 2000; Siman et al., 2000). As such, both alleles may result in partial loss-of-function with respect to $\mathrm{A} \beta_{40}$ site cleavage and possibly total PS1-dependent processing. Consistent with this notion, several published reports document that various PS1 FAD mutants exhibit impaired $\gamma$-secretase activities on APP, Notch, and cadherins (Song et al., 1999; Chen et al., 2002; Moehlmann et al., 2002; Marambaud et al., 2003; Wiley et al., 2005). Building on this common theme, it is tempting to speculate that a reduction in $\mathrm{A} \beta_{40}$ (i.e., partial lossof-function) could be the primary cause for the observed $\mathrm{A} \beta_{42}$ increase (gain-of-misfunction) and the exacerbated amyloid pathology by PS1 FAD mutations. This partial-loss-of-function model would allow reconciliation of the apparent discrepancy of the PS1 FAD effects on reduced substrate processing activity and accelerated plaque pathology. Nevertheless, an active $\gamma$-secretase complex with an imbalance of $\mathrm{A} \beta_{40}$ and $\mathrm{A} \beta_{42}$ species is likely a prerequisite for amyloid pathogenesis because reducing PS1 dosage by $50 \%$ does not promote amyloid deposition (Jankowsky et al., 2004), and genetic ablation of PS1 blocks A $\beta$ production and amyloid pathology (Dewachter et al., 2002; Saura et al., 2005).

In closing, the generation of mice with a deletion of the large hydrophilic loop sequence of endogenous PS1 allows us to address the physiological function of this domain in $\beta$-catenin regulation and $\gamma$-secretase activity. We report here that the loop sequence plays a modulatory role in $\gamma$-secretase cleavage and, importantly, that a reduced $\gamma$-secretase activity, not an increased $\mathrm{A} \beta_{42}$, is the underlying mechanism for enhanced amyloid pathology. Our results support a protective role of $\mathrm{A} \beta_{40}$ against amyloid deposition and raise the possibility that a partial loss-of-function could be the mechanism for $\mathrm{AD}$ pathogenesis in general.

\section{References}

Annaert W, De Strooper B (2002) A cell biological perspective on Alzheimer's disease. Annu Rev Cell Dev Biol 18:25-51.

Baki L, Marambaud P, Efthimiopoulos S, Georgakopoulos A, Wen P, Cui W, Shioi J, Koo E, Ozawa M, Friedrich VL Jr, Robakis NK (2001) Presenilin-1 binds cytoplasmic epithelial cadherin, inhibits cadherin/ 
p120 association, and regulates stability and function of the cadherin/ catenin adhesion complex. Proc Natl Acad Sci USA 98:2381-2386.

Berezovska O, Lleo A, Herl LD, Frosch MP, Stern EA, Bacskai BJ, Hyman BT (2005) Familial Alzheimer's disease presenilin 1 mutations cause alterations in the conformation of presenilin and interactions with amyloid precursor protein. J Neurosci 25:3009-3017.

Brown MS, Ye J, Rawson RB, Goldstein JL (2000) Regulated intramembrane proteolysis: a control mechanism conserved from bacteria to humans. Cell 100:391-398.

Cervantes S, Saura CA, Pomares E, Gonzalez-Duarte R, Marfany G (2004) Functional implications of the presenilin dimerization: reconstitution of gamma-secretase activity by assembly of a catalytic site at the dimer interface of two catalytically inactive presenilins. J Biol Chem 279:36519-36529.

Chen F, Gu Y, Hasegawa H, Ruan X, Arawaka S, Fraser P, Westaway D, Mount H, St George-Hyslop P (2002) Presenilin 1 mutations activate gamma 42 -secretase but reciprocally inhibit epsilon-secretase cleavage of amyloid precursor protein (APP) and S3-cleavage of notch. J Biol Chem 277:36521-36526.

De Strooper B, Annaert W, Cupers P, Saftig P, Craessaerts K, Mumm JS, Schroeter EH, Schrijvers V, Wolfe MS, Ray WJ, Goate A, Kopan R (1999) A presenilin-1-dependent gamma-secretase-like protease mediates release of Notch intracellular domain. Nature 398:518-522.

Dewachter I, Reverse D, Caluwaerts N, Ris L, Kuiperi C, Van den Haute C, Spittaels K, Umans L, Serneels L, Thiry E, Moechars D, Mercken M, Godaux E, Van Leuven F (2002) Neuronal deficiency of presenilin 1 inhibits amyloid plaque formation and corrects hippocampal long-term potentiation but not a cognitive defect of amyloid precursor protein [V717I] transgenic mice. J Neurosci 22:3445-3453.

Donoviel DB, Hadjantonakis AK, Ikeda M, Zheng H, Hyslop PS, Bernstein A (1999) Mice lacking both presenilin genes exhibit early embryonic patterning defects. Genes Dev 13:2801-2810.

Esler WP, Kimberly WT, Ostaszewski BL, Diehl TS, Moore CL, Tsai JY, Rahmati T, Xia W, Selkoe DJ, Wolfe MS (2000) Transition-state analogue inhibitors of gamma-secretase bind directly to presenilin-1. Nat Cell Biol $2: 428-434$

Georgakopoulos A, Marambaud P, Efthimiopoulos S, Shioi J, Cui W, Li HC, Schutte M, Gordon R, Holstein GR, Martinelli G, Mehta P, Friedrich Jr VL, Robakis NK (1999) Presenilin-1 forms complexes with the cadherin/catenin cell-cell adhesion system and is recruited to intercellular and synaptic contacts. Mol Cell 4:893-902.

Gu Y, Sanjo N, Chen F, Hasegawa H, Petit A, Ruan X, Li W, Shier C, Kawarai T, Schmitt-Ulms G, Westaway D, St. George-Hyslop P, Fraser PE (2004) The presenilin proteins are components of multiple membrane-bound complexes that have different biological activities. J Biol Chem 279:31329-31336.

Gupta-Rossi N, Le Bail O, Gonen H, Brou C, Logeat F, Six E, Ciechanover A, Israel A (2001) Functional interaction between SEL-10, an F-box protein, and the nuclear form of activated Notch1 receptor. J Biol Chem 276:34371-34378.

Herreman A, Hartmann D, Annaert W, Saftig P, Craessaerts K, Serneels L, Umans L, Schrijvers V, Checler F, Vanderstichele H, Baekelandt V, Dressel R, Cupers P, Huylebroeck D, Zwijsen A, Van Leuven F, De Strooper B (1999) Presenilin 2 deficiency causes a mild pulmonary phenotype and no changes in amyloid precursor protein processing but enhances the embryonic lethal phenotype of presenilin 1 deficiency. Proc Natl Acad Sci USA 96:11872-11877.

Hsiao K, Chapman P, Nilsen S, Eckman C, Harigaya Y, Younkin S, Yang F, Cole G (1996) Correlative memory deficits, $A \beta$ elevation, and amyloid plaques in transgenic mice. Science 274:99-102.

Iwatsubo T (2004) The $\gamma$-secretase complex: machinery for intramembrane proteolysis. Curr Opin Neurobiol 14:379-383.

Iwatsubo T, Odaka A, Suzuki N, Mizusawa H, Nukina N, Ihara Y (1994) Visualization of $A \beta 42(43)$ and $A \beta 40$ in senile plaques with end- specific $\mathrm{A} \beta$ monoclonals: evidence that an initially deposited species is $\mathrm{A} \beta 42(43)$. Neuron 13:45-53.

Jankowsky JL, Slunt HH, Gonzales V, Jenkins NA, Copeland NG, Borchelt DR (2004) APP processing and amyloid deposition in mice haploinsufficient for presenilin 1. Neurobiol Aging 25:885-892.

Kang DE, Soriano S, Frosch MP, Collins T, Naruse S, Sisodia SS, Leibowitz G, Levine F, Koo EH (1999) Presenilin 1 facilitates the constitutive turn- over of $\beta$-catenin: differential activity of Alzheimer's disease-linked PS1 mutants in $\beta$-catenin-signaling pathway. J Neurosci 19:4229-4237.

Kang DE, Soriano S, Xia X, Eberhart CG, De Strooper B, Zheng H, Koo EH (2002) Presenilin couples the paired phosphorylation of $\beta$-catenin independent of axin: implications for $\beta$-catenin activation in tumorigenesis. Cell 110:751-762.

Kirschenbaum F, Hsu SC, Cordell B, McCarthy JV (2001) Substitution of a glycogen synthase kinase- $3 \beta$ phosphorylation site in presenilin 1 separates presenilin function from $\beta$-catenin signaling. J Biol Chem 276:7366-7375.

Koepp DM, Schaefer LK, Ye X, Keyomarsi K, Chu C, Harper JW, Elledge SJ (2001) Phosphorylation-dependent ubiquitination of cyclin E by the SCFFbw7 ubiquitin ligase. Science 294:173-177.

Kopan R, Ilagan MX (2004) $\gamma$-secretase: proteasome of the membrane? Nat Rev Mol Cell Biol 5:499-504.

Kulic L, Walter J, Multhaup G, Teplow DB, Baumeister R, Romig H, Capell A, Steiner H, Haass C (2000) Separation of presenilin function in amyloid $\beta$-peptide generation and endoproteolysis of Notch. Proc Natl Acad Sci USA 97:5913-5918.

Li YM, Lai MT, Xu M, Huang Q, DiMuzio-Mower J, Sardana MK, Shi XP, Yin KC, Shafer JA, Gardell SJ (2000a) Presenilin 1 is linked with $\gamma$-secretase activity in the detergent solubilized state. Proc Natl Acad Sci USA 97:6138-6143.

Li YM, Xu M, Lai MT, Huang Q, Castro JL, DiMuzio-Mower J, Harrison T, Lellis C, Nadin A, Neduvelil JG, Register RB, Sardana MK, Shearman MS, Smith AL, Shi XP, Yin KC, Shafer JA, Gardell SJ (2000b) Photoactivated $\gamma$-secretase inhibitors directed to the active site covalently label presenilin 1. Nature 405:689-694.

Marambaud P, Shioi J, Serban G, Georgakopoulos A, Sarner S, Nagy V, Baki L, Wen P, Efthimiopoulos S, Shao Z, Wisniewski T, Robakis NK (2002) A presenilin- $1 / \gamma$-secretase cleavage releases the E-cadherin intracellular domain and regulates disassembly of adherens junctions. EMBO J 21:1948-1956

Marambaud P, Wen PH, Dutt A, Shioi J, Takashima A, Siman R, Robakis NK (2003) A CBP binding transcriptional repressor produced by the PS1/ $\epsilon$ cleavage of N-cadherin is inhibited by PS1 FAD mutations. Cell 114:635-645.

McGowan E, Pickford F, Kim J, Onstead L, Eriksen J, Yu C, Skipper L, Murphy MP, Beard J, Das P, Jansen K, Delucia M, Lin WL, Dolios G, Wang R, Eckman CB, Dickson DW, Hutton M, Hardy J, Golde T (2005) A $\beta 42$ is essential for parenchymal and vascular amyloid deposition in mice. Neuron 47:191-199.

Moehlmann T, Winkler E, Xia X, Edbauer D, Murrell J, Capell A, Kaether C, Zheng H, Ghetti B, Haass C, Steiner H (2002) Presenilin-1 mutations of leucine 166 equally affect the generation of the Notch and APP intracellular domains independent of their effect on A $\beta 42$ production. Proc Natl Acad Sci USA 99:8025-8030.

Nicolas M, Wolfer A, Raj K, Kummer JA, Mill P, van Noort M, Hui CC, Clevers H, Dotto GP, Radtke F (2003) Notch1 functions as a tumor suppressor in mouse skin. Nat Genet 33:416-421.

Qyang Y, Chambers SM, Wang P, Xia X, Chen X, Goodell MA, Zheng H (2004) Myeloproliferative disease in mice with reduced presenilin gene dosage: effect of $\gamma$-secretase blockage. Biochemistry 43:5352-5359.

Saura CA, Tomita T, Davenport F, Harris CL, Iwatsubo T, Thinakaran G (1999) Evidence that intramolecular associations between presenilin domains are obligatory for endoproteolytic processing. J Biol Chem 274:13818-13823.

Saura CA, Tomita T, Soriano S, Takahashi M, Leem JY, Honda T, Koo EH, Iwatsubo T, Thinakaran G (2000) The nonconserved hydrophilic loop domain of presenilin (PS) is not required for PS endoproteolysis or enhanced $A \beta 42$ production mediated by familial early onset Alzheimer's disease-linked PS variants. J Biol Chem 275:17136-17142.

Saura CA, Chen G, Malkani S, Choi SY, Takahashi RH, Zhang D, Gouras GK, Kirkwood A, Morris RG, Shen J (2005) Conditional inactivation of presenilin 1 prevents amyloid accumulation and temporarily rescues contextual and spatial working memory impairments in amyloid precursor protein transgenic mice. J Neurosci 25:6755-6764.

Schroeter EH, Ilagan MX, Brunkan AL, Hecimovic S, Li YM, Xu M, Lewis HD, Saxena MT, De Strooper B, Coonrod A, Tomita T, Iwatsubo T, Moore CL, Goate A, Wolfe MS, Shearman M, Kopan R (2003) A presenilin dimer at the core of the $\gamma$-secretase enzyme: insights from parallel 
analysis of Notch 1 and APP proteolysis. Proc Natl Acad Sci USA 100:13075-13080.

Shah S, Lee SF, Tabuchi K, Hao YH, Yu C, LaPlant Q, Ball H, Dann III CE, Sudhof T, Yu G (2005) Nicastrin functions as a $\gamma$-secretase-substrate receptor. Cell 122:435-447.

Siman R, Reaume AG, Savage MJ, Trusko S, Lin YG, Scott RW, Flood DG (2000) Presenilin-1 P264L knock-in mutation: differential effects on A $\beta$ production, amyloid deposition, and neuronal vulnerability. J Neurosci 20:8717-8726.

Song W, Nadeau P, Yuan M, Yang X, Shen J, Yankner BA (1999) Proteolytic release and nuclear translocation of Notch-1 are induced by presenilin-1 and impaired by pathogenic presenilin-1 mutations. Proc Natl Acad Sci USA 96:6959-6963.

Soriano S, Kang DE, Fu M, Pestell R, Chevallier N, Zheng H, Koo EH (2001) Presenilin 1 negatively regulates $\beta$-catenin/T cell factor/lymphoid enhancer factor-1 signaling independently of $\beta$-amyloid precursor protein and notch processing. J Cell Biol 152:785-794.

Tarassishin L, Yin YI, Bassit B, Li YM (2004) Processing of Notch and amyloid precursor protein by $\gamma$-secretase is spatially distinct. Proc Natl Acad Sci USA 101:17050-17055.

Tetzlaff MT, Yu W, Li M, Zhang P, Finegold M, Mahon K, Harper JW, Schwartz RJ, Elledge SJ (2004) Defective cardiovascular development and elevated cyclin E and Notch proteins in mice lacking the Fbw7 F-box protein. Proc Natl Acad Sci USA 101:3338-3345.

Thinakaran G (1999) The role of presenilins in Alzheimer's disease. J Clin Invest 104:1321-1327.

Tournoy J, Bossuyt X, Snellinx A, Regent M, Garmyn M, Serneels L, Saftig P, Craessaerts K, De Strooper B, Hartmann D (2004) Partial loss of presenilins causes seborrheic keratosis and autoimmune disease in mice. Hum Mol Genet 13:1321-1331.
Wiley JC, Hudson M, Kanning KC, Schecterson LC, Bothwell M (2005) Familial Alzheimer's disease mutations inhibit $\gamma$-secretase-mediated liberation of $\beta$-amyloid precursor protein carboxy-terminal fragment. J Neurochem 94:1189-1201.

Wolfe MS, Xia W, Ostaszewski BL, Diehl TS, Kimberly WT, Selkoe DJ (1999) Two transmembrane aspartates in presenilin-1 required for presenilin endoproteolysis and $\gamma$-secretase activity. Nature 398:513-517.

Wu G, Hubbard EJ, Kitajewski JK, Greenwald I (1998) Evidence for functional and physical association between Caenorhabditis elegans SEL-10, a Cdc4p-related protein, and SEL-12 presenilin. Proc Natl Acad Sci USA 95:15787-15791.

Xia X, Qian S, Soriano S, Wu Y, Fletcher AM, Wang X-J, Koo EH, Wu X, Zheng $H$ (2001) Loss of presenilin 1 is associated with enhanced $\beta$-catenin signaling and skin tumorigenesis. Proc Natl Acad Sci USA 98:10863-10868.

Xia X, Wang P, Sun X, Soriano S, Shum WK, Yamaguchi H, Trumbauer ME, Takashima A, Koo EH, Zheng H (2002) The aspartate-257 of presenilin 1 is indispensable for mouse development and production of $\beta$-amyloid peptides through $\beta$-catenin-independent mechanisms. Proc Natl Acad Sci USA 99:8760-8765.

Yan R, Bienkowski MJ, Shuck ME, Miao H, Tory MC, Pauley AM, Brashier JR, Stratman NC, Mathews WR, Buhl AE, Carter DB, Tomasselli AG, Parodi LA, Heinrikson RL, Gurney ME (1999) Membrane-anchored aspartyl protease with Alzheimer's disease $\beta$-secretase activity. Nature 402:533-537.

Yu G, Chen F, Levesque G, Nishimura M, Zhang DM, Levesque L, Rogaeva E, Xu D, Liang Y, Duthie M, St George-Hyslop PH, Fraser PE (1998) The presenilin 1 protein is a component of a high molecular weight intracellular complex that contains $\beta$-catenin. J Biol Chem 273:16470-16475. 